\title{
Assessment of plastic hinge in RC structures with and without shear walls applying pushover analysis
}

\author{
Jean Pierre Lukongo Ngenge ${ }^{1 *}$, Abdallah M. S. Wafi ${ }^{1}$ \\ ${ }^{1}$ Researcher, Civil Engineering Department, Near East University, Nicosia, Via Mersin 10, Turkey \\ johnlukongo@gmail.com, abdwafi1991@gmail.com
}

\begin{abstract}
This paper gives a brief presentation about different types of analysis, plastic hinge, moment-resisting frames (MRFs) and shear walls (SWs) in reinforced concrete (RC) Structures. ETABS computer software is employed to model and analyse the structures applying the pushover. The performances of the modelled structures are also evaluated considering different parameters such as the number of stories, spans length, shear walls, reinforcement yield strength and characteristic strength of concrete. The study includes two cases, which are momentresisting frames with and without shear walls (i.e. MRFs and MRF-SWs, respectively). Each case covers low-, mid- and highrise buildings. In this regard, a comparative study has been performed for the results obtained from all models. It was observed that the stiffness of MRFs compared to MRF-SWs was less and also the stiffness of low-rise frames was higher than that of midrise and high-rise frames. Technically this means that a low-rise building is stiffer than a mid-rise building and a mid-rise building is stiffer than a high-rise building. Additionally, when the span length increases, the stiffness of the building decreases. Therefore, it can be concluded that the span length is inversely proportional to the stiffness. Finally, all stiffness values were calculated taking into consideration the displacement and base shear at the first hinge formation on the pushover curve of each model.
\end{abstract}

KEYWORDS: Moment-resisting frame, plastic hinge, pushover analysis, shear wall.

\section{INTRODUCTION}

Generally there exist two main types of seismic analysis which are static and dynamic. Under static, there are linear static (equivalent lateral force) and nonlinear static (Pushover) methods. Under dynamic, there are linear dynamic (response spectrum) and nonlinear dynamic (timehistory) methods (FEMA-356, 2000; ASCE/SEI 7). Using a linear static method for the analysis of structures is good, but the ultimate load that they could exactly or approximately withstand may not be estimated properly by the designer. This is due to the assumption made in taking into consideration the maximum load that the structure could support as the load that first causes the stress somewhere in the structure (McCormac, 1992). That is why it is important to use a method which performs more than this one. The method utilized in this study is the pushover analysis. It is economical and provides a good simulation of what can happen in a real structure (Hassaballa, 2014). Pushover analysis is a static analysis, which focused on the nonlinearity of a structure. That means the structure is analyzed beyond its linear capacity by keeping on increasing the push magnitude at the top floor up to its collapse point using ETABS. This push magnitude is considered as the lateral force induced by the earthquake or wind (Hassaballa, 2014; Sujani et al. 2012). The load at which the building collapse is known as the ultimate load and the corresponding displacement is known as the maximum displacement. For better safety and economy of the structure, it is preferable to design the structure using the load at collapse (Kamath et al. 2016; Papanikolaou et al. 2008).

The pushover analysis is applied to moment-resisting frames (MRFs). MRFs are frame types made by using horizontal members (beams) and vertical members (columns). Beams are connected to columns and the opposition to the lateral forces is given by the rigid frame action. This action is done in the joints and members through the development of bending moment and shear force (Bruneau et al. 2011; Izadinia et al. 2012). The frame members' strength and bending rigidity is consequently the principal source of lateral stiffness and strength for the entire frame. (Bruneau et al. 2011; Tomas et al, 2017).

In order to resist lateral loads, a lateral load resisting system has to be added to the frame thereby increasing the stiffness of the frame. This structure is called momentresisting frame with the shear wall (MRF-SW). In the case of slender walls, SWs resist loads due to the cantilever action where the deformation as a result of bending is more. SWs may be plain or flanged in the section while core walls consist of channel sections. They provide strength and stiffness in order to control the displacement. Additionally, their shapes and location affect the structure's performance noticeably. Their best position is in the centre of each half of the building but this is rarely practised because it utilizes a lot of space; that is why their positions use to be at the ends. Furthermore, it is preferable to utilize SWs without openings in them. That is the reason why they are provided around the lift shafts and stairwells. Finally, if no opening is required to the sidewalls, SWs may be provided (Civil simplified, 2017).

The ability of a member such as a beam or column not to deform under the application of load is called stiffness. 
One of the aims during the design of a building is to ensure that members cannot experience damages and cracks which may lead them to collapse after the construction process. Therefore, the discussion about stiffness is very important (Das \& Choudhury, 2019). From hook's law, stiffness is the ratio of the applied force to the displacement. Stiffness is denoted by ' $\mathrm{K}$ '.

When a load is applied on a member and displace it, the plastic hinge will be formed as explained below. Fundamentally there is a difference between a real hinge and a plastic hinge; the moment for the first is always zero and the moment for the second is not the case. When load is increased on a particular beam, the bending moment also increases. At this stage, stresses develop in the beam and the last fibre of the beam yields. The moment that causes this yielding is called yield moment (My). If the bending continues to increase, the stress also will continue to develop until when the full section yields. At this level, a plastic hinge forms and the moment that caused this situation is called plastic moment (Mp). (McCormac, 1992; Scott and Fenves, 2006; Pokhrel and Bandelt, 2019). In the structural engineering beam theory, plastic hinge is the deformation of a section of the beam where plastic bending occurs. A kinetic mechanism allowing a complete movement of the system can be formed by incorporating a plastic hinge at a limited load into a statically indeterminate beam. This is known as the collapse mechanism. For the collapse mechanism to occurs, an additional plastic hinge must be added when considering each degree of static indeterminacy of the beam. $\mathrm{N}=$ Static indeterminacy degree +1 , where $\mathrm{N}$ is the number of plastic hinges. (McCormac, 1992; Scott and Fenves, 2006; Pokhrel and Bandelt, 2019).

\section{METHODOLOGY}

This Section deals with the methods used for analyses of all models in order to get reasonable results. Analyses chosen for this study are linear static method as well as the nonlinear static method. The best way to do pushover analysis using ETABS or SAP is to perform the two methods where the first method involves the modelling, analysis and design of building so as to find members' sizes. The second method permits to utilise the pushover analysis from the first method's results until the collapse of the building thereby getting the maximum load that will cause the building to collapse (Shah \& Patel, 2011; Bhawna Tyagi1 \& Tyagi, 2018; Abhilash et al. 2009). These analyses are done in the fastest way using a 2018 version of ETABS software. The major topics of this section are materials properties, modelled frames, loads used, and pushover analysis.

\subsection{Materials properties}

Concrete and steel are two types of materials used. Their properties are given in Table 1 .

Table 1. Materials properties applied

\begin{tabular}{cccc}
\hline & & \multicolumn{2}{c}{ Properties } \\
\cline { 3 - 4 } No. & $\begin{array}{c}\text { Materials } \\
\text { specification }\end{array}$ & $\begin{array}{c}\text { Concrete } \\
\left(\mathbf{N} / \mathbf{m m}^{2}\right)\end{array}$ & $\begin{array}{c}\text { Steel } \\
\left(\mathbf{N} / \mathbf{m m}^{2}\right)\end{array}$ \\
\hline $\mathbf{1}$ & $f_{y}$ & - & 420 \\
$\mathbf{2}$ & $f_{c}^{\prime}$ & $360(\mathrm{C} 36)$ & - \\
$\mathbf{3}$ & $\mathrm{E}$ & 24855 & 199947 \\
\hline $\mathbf{4}$ & $\begin{array}{c}\text { Unit weight of } \\
\text { concrete }\left(\mathrm{N} / \mathrm{mm}^{3}\right)\end{array}$ & 25 & - \\
\hline
\end{tabular}

\subsection{Modelled frames}

2D RC frames have been used with and without shear wall applying pushover analysis. Nine models have been analysed in each case taking into consideration the span lengths (L) and number of stories (S)

\subsubsection{Labelling system applied for frames}

The following labelling systems have been applied for frames with and without lateral load resisting system respectively:

- $\quad \mathrm{ST}-\mathrm{N}-\mathrm{S}-\mathrm{L}-\mathrm{H}-f_{c}^{\prime}-f_{y}-\mathrm{LLRS}$

- $\quad \mathrm{ST}-\mathrm{N}-\mathrm{S}-\mathrm{L}-\mathrm{H}-f_{c}^{\prime}-f_{y}$

Coding has been applied for frames, in which:

- $\quad$ ST: The structure type (RC: Reinforced concrete)

- $\quad$ N: Number of spans (5)

- S: Number of stories (4, 7 and 10)

- $\quad$ L: Span length $(5.5 \mathrm{~m}, 6 \mathrm{~m}$ and $6.5 \mathrm{~m})$

- $\quad \mathrm{H}$ : Story height $(3.2 \mathrm{~m})$

- $\boldsymbol{f}_{c}^{\prime}$ : Compressive strength of concrete

- $\boldsymbol{f}_{\boldsymbol{y}}$ : Rebar Yield strength

- LLRS: Lateral load resisting system (SW200 for shear wall with a thickness of $20 \mathrm{~cm}$ )

\subsubsection{Frames' geometry}

The support reactions for columns and shear walls at the bottom story were considered fixed. The frame geometries that have been used for all models are given in Table 2 . 
Table 2. Member's geometry

\begin{tabular}{ccc}
\hline & Member type & $\begin{array}{c}\text { Member size } \\
(\mathbf{m m})\end{array}$ \\
\hline $\mathbf{1}$ & Beams & $250 \times 500$ \\
$\mathbf{2}$ & Columns & $300 \times 600$ \\
$\mathbf{3}$ & Shear wall's thickness & 200 \\
\hline
\end{tabular}

\subsubsection{Illustrated examples of modelled frames}

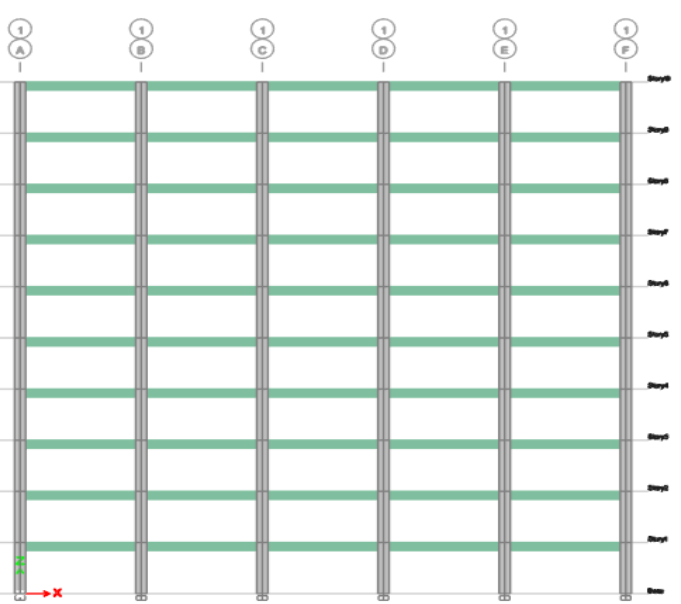

Fig. 1. Illustration of MRF taking RC-5-0-5.5-3.2-360420 as an example

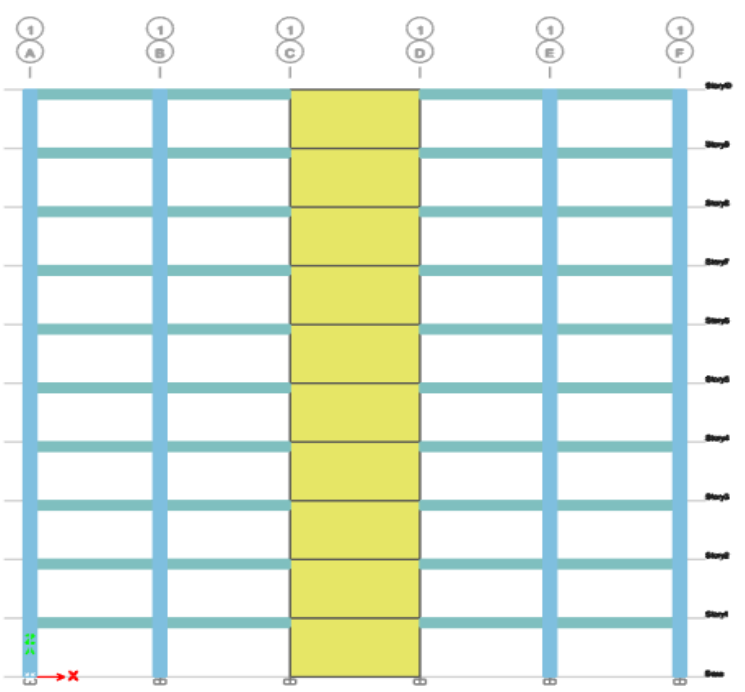

Fig. 2. Illustration of MRF-SW taking RC-5-10-5.5-3.2360-420-SW200 as an example

\subsection{Gravity loads used}

Live, dead, and super dead loads are 3 types of load utilised in all 18 models. Among them, only 2 loads were inputted because the dead load is automatically calculated by the software itself. Live load as well as super dead load were defined and assigned to beams as $5 \mathrm{kN} / \mathrm{m}$ and $10 \mathrm{kN} / \mathrm{m}$ respectively.

This work is licensed under Creative Commons Attribution 4.0 International License.

London Tech Press
Mainly there exist two types of pushover analyses, which are the capacity spectrum method and displacement coefficient method (Tyagi1 \& Tyagi, 2018; Naughton et al., 2017). In this particular study, the second method is used and hinges were assigned to each beam and column at a distance of $10 \%$ the length with respect to both ends (Sullivan et al. 2018).

\subsubsection{The procedure carried out for the pushover analysis}

The following procedure was carried out for the pushover analysis:

- Open the ETABS software,

- Under model initialization, check use built-in settings, select metric SI and ACI 318-14 code,

- In new model quick template define the grid as per the 2D plan and define story dimensions,

- Define material and section properties,

- Model the frame,

- Define load patterns, load combinations, mass source,

- Define load cases,

- Assign loads and hinges,

- Check the model and run the analysis,

- Display the pushover curve and calculate the stiffness as per the found values,

- Display formation of plastic hinges to different locations of the frame,

- Compare different results and conclude as per the observation.

\subsubsection{Pushover curve and stiffness (K)}

The pushover curve is a curve found after the analysis of the frame. There are three ways to specify the magnitude of load ' $\mathrm{P}$ ' to be applied to the top story of the frame. The first way is to specify directly the load ' $\mathrm{P}$ ' called full load in ETABS; the second way is to specify the displacement, and from the specified displacement a corresponding load will be applied automatically by the software. This displacement control method is the one utilised in this study, and the third method is a quasi-static method (Chandrasekaran and Roy, 2006). Stiffness (K) is calculated from results found on this curve, taking the ratio of base shear to the displacement. (Youcef et al. 2018). These values are selected considering the first plastic hinge formation on the curve, as shown by a red dot on the curve shown in Fig. 3 shows the example of selected values from the pushover curve for stiffness calculation.

\subsection{Pushover analysis (PA)}




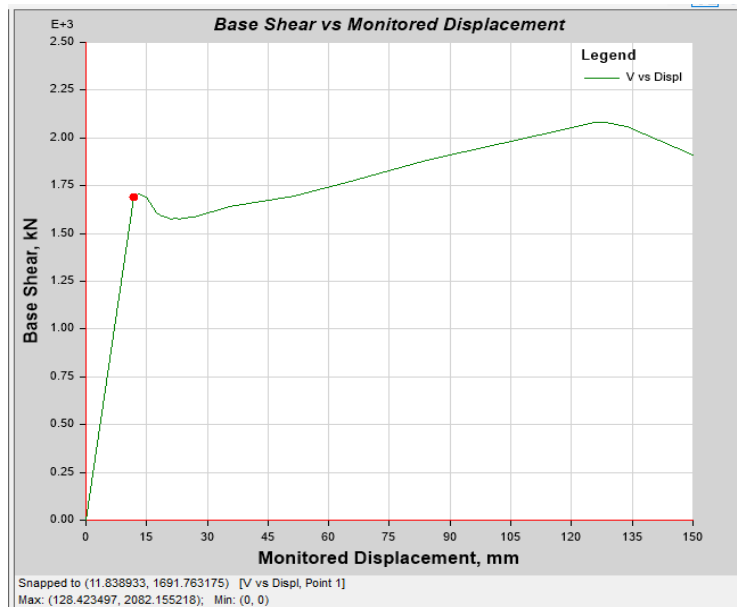

Fig. 3. Pushover curve, RC-5-4-5.5-3.2-360-420SW200

$K=\frac{V s}{D s}$

where,

$K$ : Elastic stiffness factor in $\mathrm{kN} / \mathrm{mm}$,

$V s$ : Base shear at the first plastic hinge formation,

Ds: Displacement at the first plastic hinge formation.

\section{RESULTS AND DISCUSSIONS}

\subsection{Results with respect to plastic hinge formation}

The Figs. 4 and 5 are two examples taken in order to show the plastic hinge formation. It is observed that Fig. 4 has plastic hinge formation from row "B" to " $D$ " (BCD) and Fig. 5 has from " $\mathrm{B}$ " to "C" (BC). It means that Fig. 5 is stiffer than Fig. 4 due to shear wall's provision. Shear wall imparts more stiffness to the structure when provided. It is important to note that members forming the second and fourth spans in Fig. 5 need to be well designed in order to prevent collapse. The reason is clearly shown in Fig. 5 by colours of the plastic hinge on the second span of each story from left. Additionally, when observing story one on the Fig. 4, the resulting hinge colours show that the building is not much safe at that part, and the first column is not safe at its base. Plastic hinges are represented in different colours based on the plastic situation at a particular location, and they are explained below:

- Elastic range

- Beginning of yielding,

- Ultimate strength

- Residual strength

- Maximum residual strength deformation

BCDE: Plastic range.

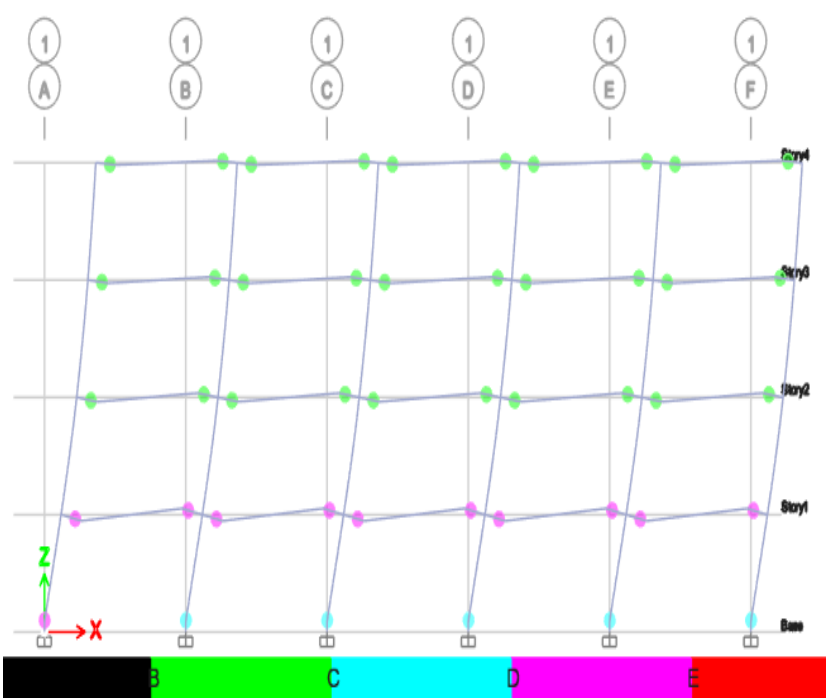

Fig. 4. Plastic hinge formation, $\mathrm{RC}-5-4-5.5-3.2-$ $360-420$

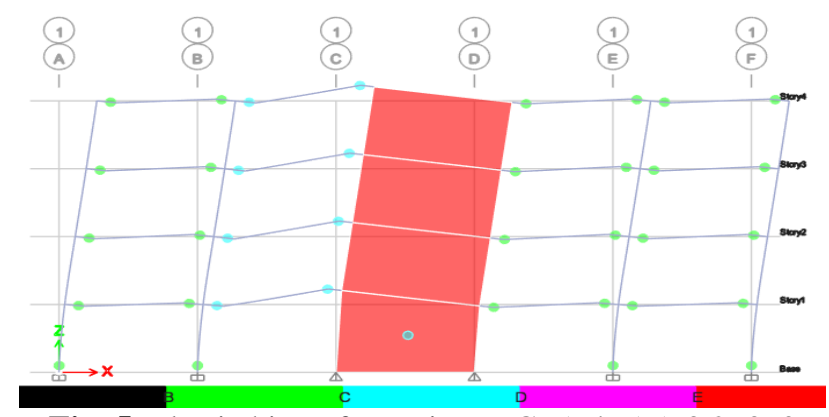

Fig. 5. Plastic hinge formation, RC-5-4-5.5-3.2-360420-SW200

\subsection{Results with respect to pushover curve}

This section deals with results and discussions of 2D RC frames that were analyzed based on parametric study in the previous sections. These results are mainly focused on the assessment of the plastic hinge in terms of elastic stiffness (K). When the first plastic hinge forms, these results are utilized to probe the effect of two factors on the responsiveness of moment resisting frame with and without shear wall. The factors considered in this study are span lengths and number of stories. This section has two subsections which are factors affecting the elastic stiffness and comparison between the variation of span length and number of stories.

\subsubsection{Factors affecting the elastic stiffness}

\subsubsection{The effect of span length on the elastic stiffness factor of MRFs and MRF-SWs}

Change in span length is one of the factors that influence the stiffness and seismic performance of shear walls. Any change in span length leads to a decrease or increase in the stiffness of the structure. It is found that the elastic stiffness 
factor of MRFs decreases by increasing the span length. In the case of MRF-SWs the stiffness decreases by increasing the span lengths for low-rise building. For mid-rise buildings varying from 7 to 10 stories, the stiffness increase than that of low-rise building. This means that shear walls work well in mid-rise buildings than low-rise. Additionally MRFs has the lowest elastic stiffness factors than MRFSWs. It is as shown in Figs. 6 and 7 as well as in Tables 3 and 4.

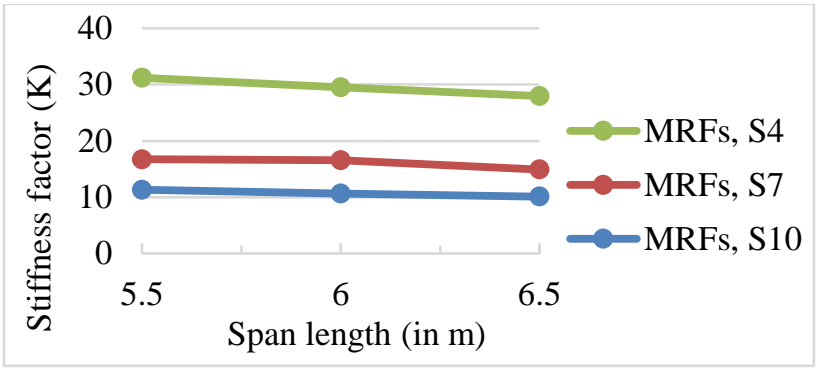

Fig. 6. K of MRFs versus different span lengths

Table 3. K of MRFs versus different span lengths

\begin{tabular}{cccc}
\hline \multirow{3}{*}{$\mathbf{3}$} & \multicolumn{3}{c}{$\mathbf{K}$} \\
\cline { 2 - 4 } & $\mathbf{5 . 5} \mathbf{~ m}$ & $\mathbf{6 ~} \mathbf{~}$ & $\mathbf{6 . 5} \mathbf{~ m}$ \\
\hline $\mathbf{4}$ & 31.21 & 29.50 & 27.96 \\
$\mathbf{7}$ & 16.75 & 16.61 & 14.90 \\
$\mathbf{1 0}$ & 11.33 & 10.68 & 10.09 \\
\hline
\end{tabular}

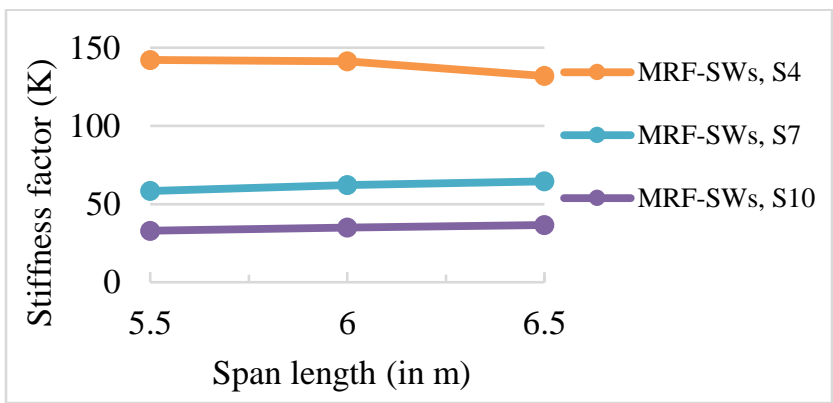

Fig. 7. K of MRF-SWs versus different span lengths

Table 4. K of MRF-SWs versus different span lengths

\begin{tabular}{cccc}
\hline $\mathbf{S}$ & \multicolumn{3}{c}{$\mathbf{K}$} \\
\cline { 2 - 4 } & $\mathbf{5 . 5} \mathbf{~ m}$ & $\mathbf{6 ~ \mathbf { ~ }}$ & $\mathbf{6 . 5} \mathbf{~ m}$ \\
\hline $\mathbf{4}$ & 142.16 & 141.28 & 131.88 \\
$\mathbf{7}$ & 58.33 & 62.18 & 64.51 \\
$\mathbf{1 0}$ & 32.95 & 34.85 & 36.60 \\
\hline
\end{tabular}

\subsubsection{The effect of the number of stories on the elastic stiffness factor of MRFs and MRF-SWs}

Change in the number of stories is one of the factors that affects the stiffness of the building. It has an unfavourable effect on the stiffness of the MRFs and MRF-SWs. Therefore, any increase in the number of stories leads to an increase in the deflection of the structure and a decrease in lateral stiffness. When the number of stories increases, the elastic stiffness factor decreases. Values in the Figs. 8 and 9 as well as Tables 5 and 6 are with respect to an example of RC-5-(4, 7, 10)-6-3.2-360-420 and RC-5-(4, 7, 10)-6$3.2-360-420-$ SW200.

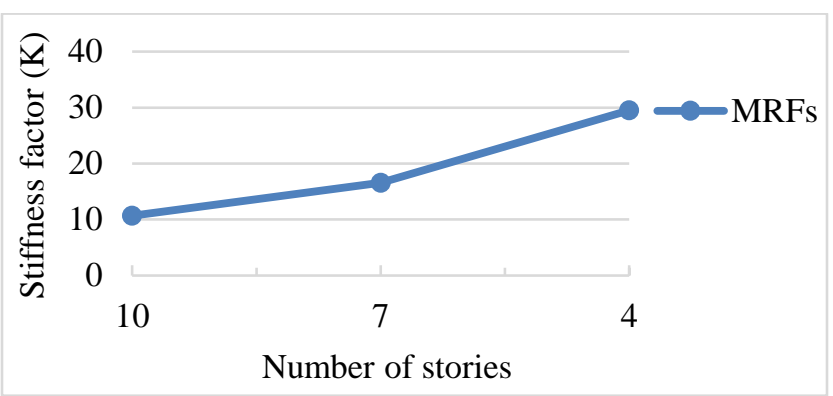

Fig. 8. K of MRFs vs. different number of stories

Table 5. K of MRFs vs. different number of stories

\begin{tabular}{cc}
$\mathbf{S}$ & $\mathbf{K}$ \\
\hline $\mathbf{4}$ & 29.50 \\
$\mathbf{7}$ & 16.61 \\
$\mathbf{1 0}$ & 10.68 \\
\hline
\end{tabular}

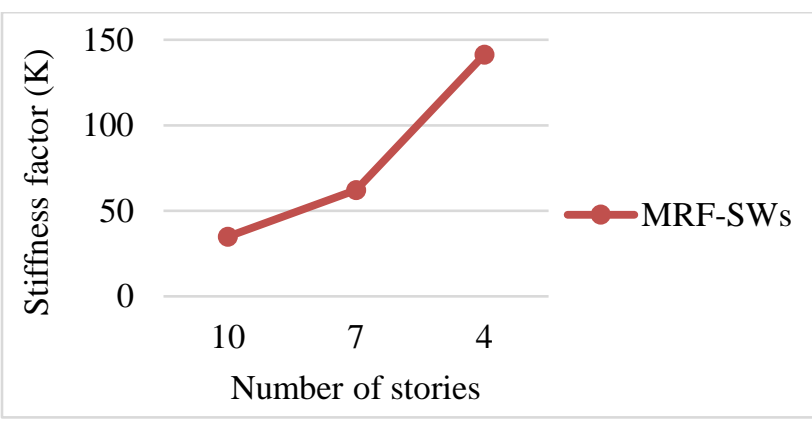

Fig. 9. K of MRF-SWs vs. different number of stories

Table 6. K of MRF-SWs vs. different number of stories

\begin{tabular}{cc}
$\mathbf{S}$ & $\mathbf{K}$ \\
\hline $\mathbf{4}$ & 141.28 \\
$\mathbf{7}$ & 62.18 \\
$\mathbf{1 0}$ & 34.85 \\
\hline
\end{tabular}




\subsubsection{Comparison between MRFs and MRF-SWs on their performances}

This Section deals with the performance comparison between the elastic stiffness factor of MRFs and MRF-SWs in terms of span lengths and number of stories.

\subsubsection{Comparison between MRFs and MRF-SWs on the} number of stories and elastic stiffness factor with respect to different span lengths.

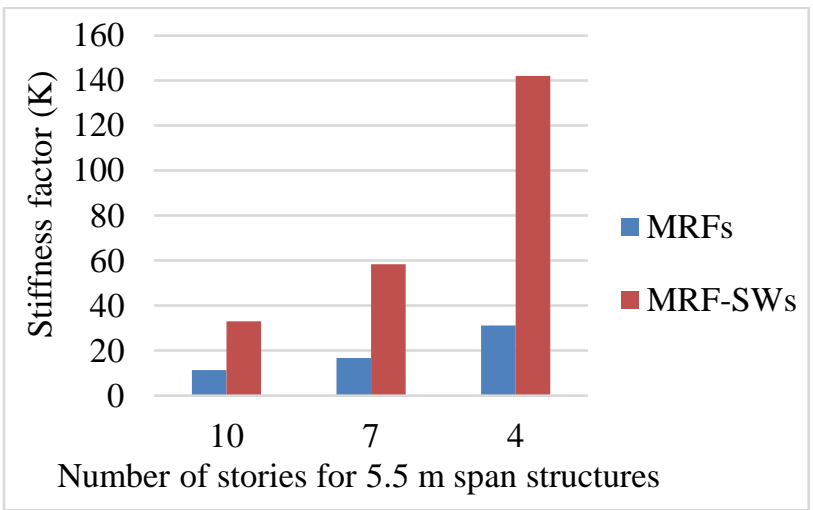

Fig. 10. $\mathrm{K}$ versus the number of stories

Table 7. Comparison between MRFs and MRF-SWs with respect to $\mathrm{K}$

\begin{tabular}{cccc}
$\mathbf{L}(\mathbf{m})$ & $\mathbf{S}$ & $\mathbf{K}$ for MRFs & K for MRF-SWs \\
\hline \multirow{3}{*}{$\mathbf{5 . 5}$} & 4 & 31.21 & 142.16 \\
& 7 & 16.75 & 58.33 \\
& 10 & 11.33 & 32.95 \\
\hline
\end{tabular}

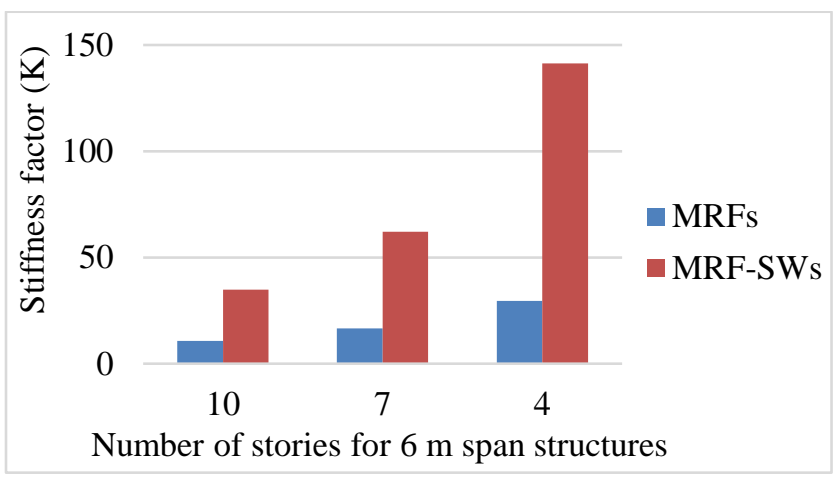

Fig. 11. $\mathrm{K}$ versus the number of stories
Table 8. Comparison between MRFs and MRF-SWs with respect to $\mathrm{K}$

\begin{tabular}{cccc}
$\mathbf{L}(\mathbf{m})$ & $\mathbf{S}$ & $\mathbf{K}$ for MRFs & K for MRF-SWs \\
\hline \multirow{6}{*}{$\mathbf{6}$} & 4 & 29.50 & 141.28 \\
& 7 & 16.61 & 62.18 \\
& 10 & 10.68 & 34.85 \\
\hline
\end{tabular}

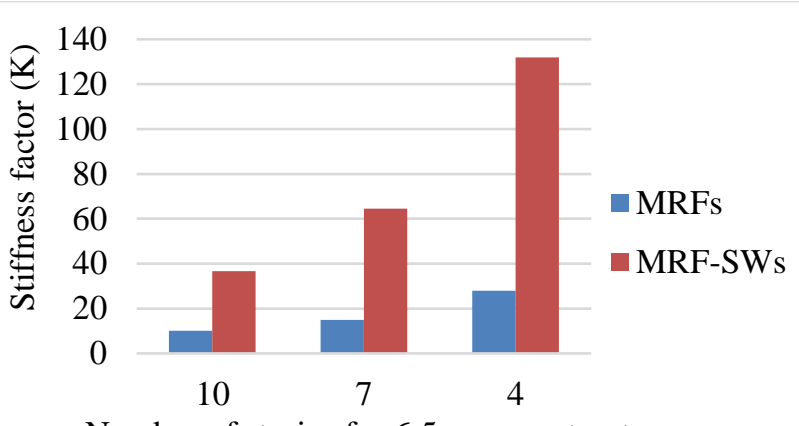

Number of stories for $6.5 \mathrm{~m}$ span structures

Fig. 12. K versus the number of stories

Table 9. Comparison between MRFs and MRF-SWs with respect to $\mathrm{K}$

\begin{tabular}{cccc}
\hline $\mathbf{L}(\mathbf{m})$ & $\mathbf{S}$ & $\mathbf{K}$ for MRFs & K for MRF-SWs \\
\hline \multirow{6}{*}{6.5} & 4 & 27.96 & 131.88 \\
& 7 & 14.90 & 64.51 \\
& 10 & 10.09 & 36.60
\end{tabular}

3.2.2.2. Comparison between MRFs and MRF-SWs on the effect of span length to the elastic stiffness factor

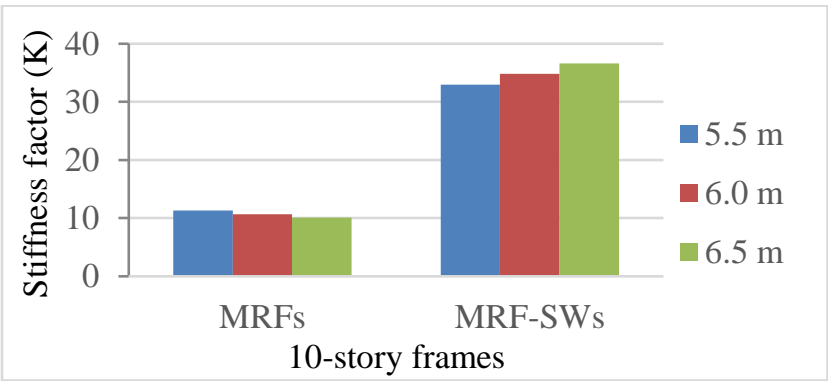

Fig. 13. K versus 10-story structures

Table 10. Comparison between MRFs and MRF-SWs with respect to $\mathrm{K}$ for 10 -story structure

\begin{tabular}{ccc}
\hline $\mathbf{L}(\mathbf{m})$ & K for MRFs & K for MRF-SWs \\
\hline $\mathbf{5 . 5}$ & 11.33 & 32.95 \\
$\mathbf{6}$ & 10.68 & 34.85 \\
$\mathbf{6 . 5}$ & 10.09 & 36.60 \\
\hline
\end{tabular}




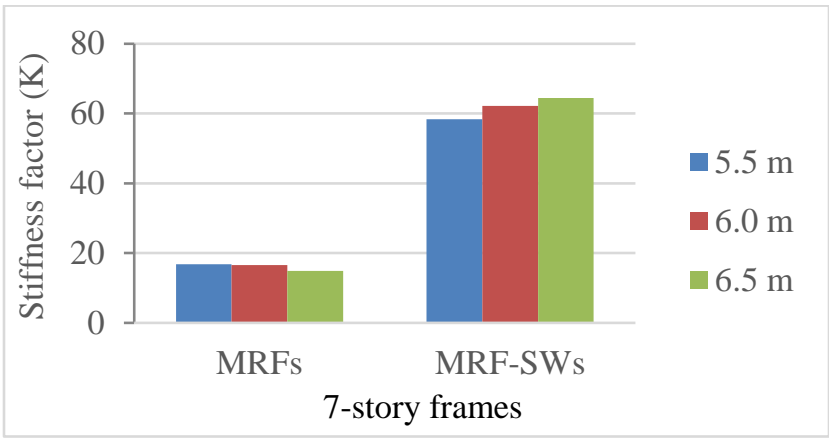

Fig. 14. $\mathrm{K}$ versus 7 -story structures

Table 11. Comparison between MRFs and MRF-SWs with respect to $\mathrm{K}$ for 7 -story structure

\begin{tabular}{ccc}
\hline $\mathbf{L}(\mathbf{m})$ & K for MRFs & $\begin{array}{c}\text { K for MRF- } \\
\text { SWs }\end{array}$ \\
\hline $\mathbf{5 . 5}$ & 16.75 & 58.33 \\
$\mathbf{6}$ & 16.61 & 62.18 \\
$\mathbf{6 . 5}$ & 14.90 & 64.51 \\
\hline
\end{tabular}

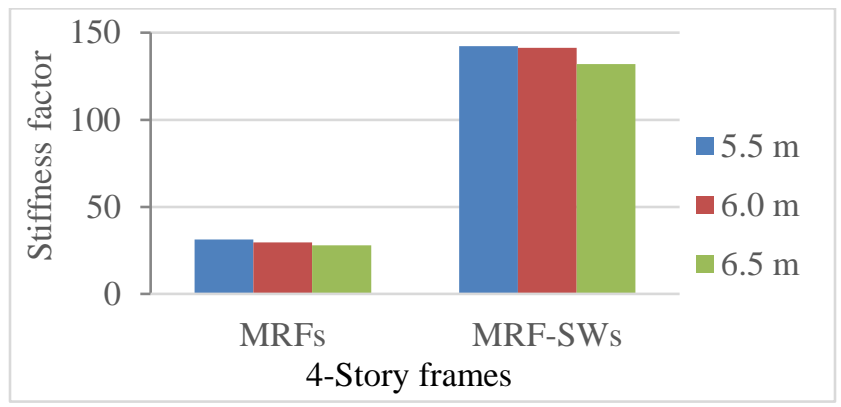

Fig. 15. $\mathrm{K}$ versus 4 -story structure

Table 12. Comparison between MRFs and MRF-SWs with respect to $\mathrm{K}$ for a 4-story structure

\begin{tabular}{ccc}
\hline L (m) & K for MRFs & K for MRF-SWs \\
\hline $\mathbf{5 . 5}$ & 31.21 & 142.16 \\
$\mathbf{6}$ & 29.50 & 141.28 \\
$\mathbf{6 . 5}$ & 27.96 & 131.88 \\
\hline
\end{tabular}

\section{CONCLUSIONS}

This paper included the assessment of plastic hinge in $\mathrm{RC}$ structures with and without shear walls applying pushover analysis in ETABS. It was divided into three main parts. The first part, which is the introduction helped to understand the different terms used in the study. The second part helped to understand the methodology used and the third part helped to understand the outcomes of the study, which are results. It was observed that the stiffness of MRFs compared to MRF-SWs was less. This means that the structure is stiffer when shear wall is provided than when it is not. Also, the stiffness of the low-rise frame was higher than that of mid-rise and high-rise frames. Technically this means that a low-rise building is stiffer than a mid-rise building and a mid-rise is stiffer than a high-rise building. Additionally, when the span length increases, the stiffness of the building decreases in case of MRFs and MRF-SWs when the shear wall geometry is the same for all types of structures. It can be concluded that the span length is inversely proportional to the stiffness. When the shear wall geometry is not the same for all structures, the stiffness depends upon the shear wall geometry of each structure. Finally, all stiffness values were calculated, taking into consideration the displacement and base shear at the first hinge formation on the pushover curve of each model.

\section{REFERENCES}

[1] Abhilash, R. et al. (2009). Effect of lateral load patterns in pushover analysis. $10^{\text {th }}$ National conference on technological trends (NCTT09). At Ttrivandrum, India, Volume: College of Engineering Trivandrum, 1-5.

[2] ASCE (American Society of Civil Engineers). Minimum design loads for buildings and other structures, standard ASCE/SEI 7, pp. 88.

[3] Hassaballa, A. E. et al. (2014). Pushover Analysis of Existing 4 storey RC Flat Slab Building. International Journal of Sciences: Basics and applied Research (IJSBAR). 16(2), 246-247.

[4] Civil simplified. (2017). Available at: https://www.civilsimplified.com/resources/what-areshear-walls

[5] Naughton, D. T. et al. (2017). Pushover Analysis of steel seismic resistance frames with reduced web section and reduced beam section connections. Frontiers in build environment, 3:59, 1-15, https://doi.org/10.3389/fbuil.2017.00059

[6] FEMA-356 (Federal Emergency Management Agency). (2000). Prestandard and commentary for the seismic rehabilitation of buildings, pp 3-1.

[7] McCormac, J. (1992). Structural steel design, ASD Method. (4 ${ }^{\text {th }}$ ed). HarperCollins, pp. 543-546, New York.

[8] Kamath, K. et al. (2016). An analytical study on performance of a diagrid structure using nonlinear static pushover analysis. Science direct, Volume 8, September 2016, Pages 90-92, https://doi.org/10.1016/j.pisc.2016.04.004

[9] Pokhrel, M. \& Bandelt, M. J. (2019). Plastic hinge behaviour and rotation capacity in reinforced ductile concrete flexural members. Elsevier, engineering structures, 200, 2-4.

[10] Youcef, M. et al. 2018). Seismic performance of RC building using spectrum response and pushover analyses. Springer international publishing, 4.

[11] Scott, M. H. \& Fenves, G. L. (2006). Plastic Hinge Integration Methods for Force-Based Beam-Column Elements. Journal of Structural Engineering, ASCE/February 2006, 244-252. 
https://doi.org/10.1061/ASCE0733-9445006132:2244

[12] Bruneau, M. et al. (2011). Ductile Design of Steel Structures. (2 $2^{\text {nd }}$ ed.). McGraw-Hill Companies, pp 345348.

[13] Izadinia, M. et al. (2012), Response modification factor for steel moment-resisting frames by different pushover analysis methods. ELSEVIER, Journal of constructional steel research, 79 (2012) 83-90.

[14] Shah, M. D. \& Patel, S. B. (2011). Nonlinear static analysis of R.C.C. frames. National Conference on recent trends in Engineering and technology, 13-14 May 2011, India.

[15] Tyagi1, B. \& Tyagi B. S. (2018). Seismic response study of multi-storied reinforced concrete building with fluid viscous dampers. International Research Journal of Engineering and Technology (IRJET), 5(5), 22672271.

[16] Das, S. \& Choudhury, S. (2019). Influence of effective stiffness on the performance of the RC frame buildings designed using displacement-based method and evaluation of column effective stiffness using ANN. Elsevier, Engineering Structures, 197, 109353. https://doi.org/10.1016/j.engstruct.2019.109354

[17] Chandrasekaran, S. \& Roy. A. (2006). Seismic evaluation of multi-story RC frame using modal pushover analysis. Springer, nonlinear dynamics, 4.

[18] Sujani, S. N. et al. (2012). Determination of performance level of $\mathrm{G}+5$ building situated in zone 3 using pushover by sap2000. International Journal of Engineering research and applications, 2(2), 832-837.

[19] Sullivan T. J. et al. (2018). Simplified pushover analysis of moment resisting frame structures. Taylor \& Francis. Journal of earthquake engineering, First Published December 8, 2019, 208-214. https://doi.org/10.1080/13632469.2018.1528911

[20] Papanikolaou V. k. et al. (2008). Evaluation of conventional and adaptive pushover analysis II: comparative results. Taylor \& Francis, Journal of earthquake engineering, 10(1), 127-151. https://doi.org/10.1080/13632460609350590 